\title{
Decolorization of Malachite green dye by Stenotrophomonas maltophilia a compost bacterium
}

Vasudhaudupa Alaya ${ }^{1}$, Rajesh Kumar Kodi ${ }^{2}$ Earanna Ninganna ${ }^{3}$, Balakrishna Gowda ${ }^{2}$ and M. B. Shivanna ${ }^{1 *}$ (1)

\begin{abstract}
Background: The release of triphenylmethane dyes, like malachite green (MG) and crystal violet (CV), into the environment is a cause of concern due to its toxicity, mutagenicity and carcinogenicity.

Result: A bacterial strain that is capable of decolorizing both dyes was isolated from the composted neem oil-seed cake. The strain was characterized as Stenotrophomonas maltophilia based on the $16 \mathrm{~S}$ rRNA gene sequence and designated as isolate TPMD-1. The kinetic study of the dye degradation revealed the efficiency of the above isolate to degrade MG. The effect of substrate concentration, $\mathrm{pH}$, temperature, and agitation on the decolorization of MG by the isolate was also studied. The MG degradation rate was slightly more in neutral pH at $28-30^{\circ} \mathrm{C}$ and $150 \mathrm{rpm}$. The UV-spectroscopy, HPLC, and FTIR analyses of the dye sample before and after bacterial treatment revealed the high ability of S. maltophilia TPDM-1 in the removal of MG from the media. The genetic snapshot of the isolate by PCR amplification and sequencing showed the presence of genes 'lac' and ' $t m r^{\prime}$ that codes for laccase and triphenylmethane reductase.
\end{abstract}

Conclusion: This study presented the first report of Stenotrophomonas maltophilia in the degradation and detoxification of MG dye by oxidoreduction, which could be used for the bioremediation of aquatic environments contaminated by MG.

Keywords: Malachite green, Crystal violet, Dye decolorization, Exponential decay, S. maltophilia

\section{Background}

The triphenylmethane (TPM) dyes are brilliant and intense by colored synthetic dyes with $\left(\mathrm{C}_{6} \mathrm{H}_{5}\right)_{3} \mathrm{CH}$ as their backbone that finds application in the textile industry (Shah et al. 2013). This dye accounts for nearly $30-40 \%$ of total dye consumption in the dyeing of cotton, wool, and silk fabrics (Carliell et al. 1998). Besides this, these dyes are also used in coloring biological materials, wax, varnish, cosmetics, paper and leather, and plastic industries (Shah et al. 2013). Certain TPM dyes such as

\footnotetext{
*Correspondence: mbshivanna@yahoo.co.uk

1 Department of PG Studies and Research in Applied Botany, Jnana Sahyadri, Kuvempu University, Shimoga Dist., Shankaraghatta 577 451, India

Full list of author information is available at the end of the article
}

crystal violet (CV) and malachite green (MG) are extensively used in the textile industry (Wu et al. 2008) and the colored effluents are let into water bodies. These effluents contain aromatic amines and phenols that are hard to degrade (Robinson et al. 2001) and affect aquatic life by blocking the photosynthetic process (Raghukumar et al. 2008). The untreated dye effluents are also reported to be toxic to humans beings by way of injuring internal organs (Hassaan and Nemr 2016). The CV was reported to induce tumor in fishes, while MG induces hepatic tumor in rodents and causes reproductive abnormalities in rabbits and fishes (Cho et al. 2013). Because of these, the removal of TPM dyestuffs from the contaminated water source is deemed essential.

The conventional wastewater treatment does not degrade all the aromatic ring structures, including 
aromatic amines, phenols, as it is recalcitrant $(\mathrm{Du}$ et al. 2011). Hence, a combination of physico-chemical methods such as adsorption, floatation, coagulation, chemical oxidation and the use of membrane bioreactor is employed to degrade dye effluents (Wang et al. 2011). These techniques are expensive and generate vast volumes of sludge and toxic by-products that are the source of secondary pollution (Saratale et al. 2011). However, biological methods are available, which are eco-friendly and completely mineralize organic pollutants (Pandey et al. 2007). Recent developments in the field of bioremediation include the use of dye degrading microorganisms and the potential degrading enzyme system they produce (Ali et al. 2009; Wang et al. 2012; Yang et al. 2014) and metabolic pathways (Jang et al. 2005). This approach is cost-effective and environmentally friendly. Certain fungal and bacterial strains were shown to involve in the degradation of both CV and MG by the mechanism of adsorption and degradation (Ali et al. 2009; Jadhav and Govindwar 2006).

The biochemical studies of the decolorization of TPM dyes indicated that the involvement of laccases and lignin peroxidases produced by fungi and triphenylmethane reductase (TMR) produced by bacteria (Jang et al. 2005; Shin and Kim, 1998; Tekere et al. 2001). Laccases are a part of the sizeable multicopper oxidase reductase family enzymes that catalyze the four-electron reduction to water from a suitable substrate (Reiss et al. 2013). This enzyme is involved in the biodegradation of lignin, which is the noncarbohydrate polyphenolic component in the wood. Additionally, it has broad substrate specificity and is capable of degrading aromatic phenolic and non-phenolic pollutants in wastewater (Prins et al. 2015). Although fungal laccases are more extensively studied, bacterial laccases are an advantage due to their molecular nature (Prins et al. 2015; Narayanan et al. 2015; Kuppusamy et al. 2017). Similarly, triphenylmethane reductase (TMR), a member of the dehydrogenase enzyme has been reported in several bacteria that are involved in the degradation of textile dyes, particularly the MG by NADH-dependent reduction (Wang et al. 2011; Jang et al. 2005).

The present study aims to isolation of bacterial strains from compost samples capable of degrading TPM dyes, particularly the MG. Stenotrophomonas maltophilia isolated from the compost was determined for its ability to decolorize the MG and the study of the degradation kinetics. An attempt was also made to isolate and confirm the role of 'lac' and 'tmr' genes, for dye degradation in bacteria.

\section{Methods}

\section{Isolation and screening of bacterial isolates for TPM dye} degradation

The compost of neem oil-seed cake at the thermophilic stage was collected and serially diluted $\left(10^{-6}\right)$ and spread on nutrient agar plates and incubated at $37{ }^{\circ} \mathrm{C}$ for $24 \mathrm{~h}$. Individual colonies of bacteria on agar plates were identified based on the colony characteristics and pure cultures were obtained and maintained on nutrient agar. The bacterial isolates were cultured separately in mineral salt basal medium ( $3 \mathrm{~g}$ peptone, $10 \mathrm{~g}$ glucose, $0.6 \mathrm{~g} \mathrm{KH}_{2} \mathrm{PO}_{4}, 0.001 \mathrm{~g}$ $\mathrm{ZnSO}_{4}, 0.4 \mathrm{~g} \mathrm{~K}_{2} \mathrm{HPO}_{4}, 0.0005 \mathrm{~g} \mathrm{FeSO}_{4}, 0.05 \mathrm{~g} \mathrm{MnSO}_{4}$, $0.5 \mathrm{~g} \mathrm{MgSO}_{4}$ and $20 \mathrm{~g}$ agar) amended with either malachite green (MG, $\left.100 \mathrm{mg} \mathrm{L}^{-1}\right)$ or crystal violet $\left(\mathrm{CV}, 100 \mathrm{mg} \mathrm{L}^{-1}\right)$. The colony cultures were observed for the high zone of clearance. In another experiment, the bacterial culture was inoculated to mineral salt broth $(50 \mathrm{ml})$ supplemented with either the MG or $\mathrm{CV}$ at the same concentration used above and incubated at $30{ }^{\circ} \mathrm{C}$ in a shaking incubator $(150 \mathrm{rpm})$. The culture broth was collected at an interval of $24 \mathrm{~h}$ for $96 \mathrm{~h}$ and centrifuged (Mini spin, Eppendorf 10,000 rpm (g), $2 \mathrm{~min}$ ) and the supernatant was collected and the absorbance measured at $618 \mathrm{~nm}$ for MG and $590 \mathrm{~nm}$ for CV using a UV-Vis spectrophotometer (Thermo Scientific, Biomate 3S). The measurement was taken up to $96 \mathrm{~h}$, and maximum dye degradation (\%) at each time interval was calculated as:

$$
A_{0}-A_{t} / A_{0} * 100
$$

where $A_{0}$, initial absorbance of the media, $A_{t}$, absorbance of the media at the interval of ' $t$ ' time.

\section{Kinetics of dye decolorization}

The rate of decolorization of dyes was studied at a different dye concentration of 100, 200,300, 400 and $500 \mathrm{mg} \mathrm{L}^{-1}$. The bacterial isolate was inoculated to the dye mineral salt basal liquid medium supplemented with either of the dyes $\left(\mathrm{pH} 6.5\right.$ at $\left.28{ }^{\circ} \mathrm{C}\right)$. The sampling of the culture broth was done for $96 \mathrm{~h}$ at an interval of $24 \mathrm{~h}$, and the extent of degradation was determined by using the formula (1). Further, the rate of degradation of selected dyes was determined by the first-order exponential decay model:

$$
C_{t}=C_{0} e^{-\lambda t},
$$

where $\lambda=$ decolorization rate $\left(\mathrm{h}^{-1}\right), C_{0}$ and $C_{t}\left(\mathrm{mg} \mathrm{L}^{-1}\right)$ concentration of dye at the zero time and at a time ' $t$ ' (h) (Mutafov et al. 2006) using the Sigma Plot (ver. 14.0). The half-life of each dye at different concentrations was determined by

$$
t_{1 / 2}=0.693 / \lambda
$$

where $t_{1 / 2}$ is the half-life of the decay quantity. 


\section{Optimization parameters}

The effect of variation in $\mathrm{pH}$, temperature, and rate of agitation on MG dye discoloring ability of bacterial isolate was studied at $100 \mathrm{mg} \mathrm{L}^{-1} \mathrm{MG}$ dye concentration. The $24 \mathrm{~h}$ old bacterial culture $(100 \mu \mathrm{l})$ was inoculated to mineral salt liquid media $(50 \mathrm{ml})$ contained in a $100 \mathrm{ml}$ conical flask. The $\mathrm{pH}$ of the broth was adjusted to 6,7 , or 8 (using $0.1 \mathrm{~N} \mathrm{NaOH}$ or $\mathrm{HCl}$ ) and incubated at 28 , 30 or $35^{\circ} \mathrm{C}$ in a shaking incubator at static $(0 \mathrm{rpm}), 100$ or150 rpm for $48 \mathrm{~h}$. The experiment was arranged in a completely randomized design (CRD) with three replicates. The extent of decolorization of dye in each set was determined by the measuring absorbance at $618 \mathrm{~nm}$, as described previously.

\section{Biodegradation analysis}

The discolored bacterial supernatant product (without bacterial cells) of MG dye was extracted with an equal volume of ethyl acetate at $0 \mathrm{~h}$ (control) and $24 \mathrm{~h}$ (after decolorization of the medium). The extracts were evaporated to dryness over anhydrous sodium sulfate $\left(\mathrm{Na}_{2} \mathrm{SO}_{4}\right)$ and crystals obtained were dissolved in a small volume of HPLC grade methanol, and the same sample was used for HPLC and FTIR analysis (Jadhav and Govidwar, 2006). The HPLC (Shimadzu, Japan) analysis was carried out on a dual $\lambda U V$-VIS detector and a C18 column with methanol and water $(0.1 \%$ formic acid) as the mobile phase, methanol (40\%) for $2 \mathrm{~min}$. and $95 \%$ methanol for $8 \mathrm{~min}$. with a flow rate of $0.5 \mathrm{ml} \mathrm{min}{ }^{-1}$ at $40{ }^{\circ} \mathrm{C}$ and the compound (MG) detected at $265 \mathrm{~nm}$.

Fourier Transform Infrared Spectroscopy (FTIR) analysis of the degraded product of MG at 0 and $24 \mathrm{~h}$ was carried out using the Thermo Fisher Scientific instrument (FTIR Nicolet 6700FT-IR). The FTIR analysis was done in the mid-IR region of $400-4000 \mathrm{~cm}^{-1}$ at16 scan speed. The samples were mixed with spectroscopically pure potassium bromide $(\mathrm{KBr})$ in the ratio of 5:95, pellets were fixed in the sample holder, and the analysis was carried out.

\section{Phytotoxicity}

The effect of toxicity of MG before and after degradation was determined by seed germination test using sorghum (Sorghum vulgare Pers.) and finger millet (Eleusine coracana (L.) Gaertn) and by measuring radicle and plumule length. Seeds were first surface disinfected with sodium hypochlorite $(0.01 \%, 1-2 \mathrm{~min})$ and rinsed for 2-3 times with distilled water and placed in Petri dishes (20 seeds per plate) containing blotting paper discs previously soaked with MG solution $\left(100 \mathrm{mg} \mathrm{L}^{-1}\right)$, before and after treatment with bacterial culture. The Petri dishes were incubated in darkness in the laboratory conditions for 24 to $48 \mathrm{~h}$. The seed germination (\%) was calculated.

\section{Identification of dye transforming bacterial isolate by $16 \mathrm{~S}$ rRNA sequence}

Its 16S rRNA gene sequence identified the MG dye discoloring bacterial isolate TPMD- 1 . The bacterial culture was grown in the LB broth for $24 \mathrm{~h}$ and the culture was centrifuged at 10,000 rpm for $2 \mathrm{~min}$. to obtain the pellet of cells that were used for the extraction of genomic DNA. The genomic DNA of the bacterial isolate was extracted by a modified alkaline lysis method (Sambrook et al. 1989). The purified RNA-free genomic DNA was subjected to PCR amplification by using universal primers specific for $16 \mathrm{~S}$ rRNA gene forward primer (5' GTT AGATCTTGGCTCAGGACGAACGC3') and $16 \mathrm{~S}$ gene reverse primer (5' GATCCAGCCGCACCTTCCGAT ACG $\left.3^{\prime}\right)$. The amplification was performed using a thermal cycler (Eppendorf Master cycler, USA) and the reaction involved an initial denaturation at $94{ }^{\circ} \mathrm{C}$ for $1 \mathrm{~min}$ followed by 35 cycles of $94{ }^{\circ} \mathrm{C}$ for $1 \mathrm{~min}, 55^{\circ} \mathrm{C}$ for $30 \mathrm{~s}$ annealing and elongation at $72{ }^{\circ} \mathrm{C}$ for $1 \mathrm{~min}$. and the final extension was set at $72{ }^{\circ} \mathrm{C}$ for $12 \mathrm{~min}$. The amplified DNA was sequenced and analyzed using the online NCBI BLAST tool program (http://www.ncbi.nib.gov/ blast). The phylogenetic analysis was carried out to study comparative genomics to derive the evolutionary relationship of the bacterial species by using the characterbased neighbor-joining analysis method (MEGA ver.7.0), as explained in the Tamura-Nei model (Tamura and Nei 1993).

\section{Molecular snapshot of bacterial isolate for gene 'lac' and 'tmr'}

The genomic DNA of the MG degrading bacterial isolate was evaluated for the presence of laccase gene (lac) and triphenylmethane reductase gene $(t m r)$. Both genes were identified by PCR amplification using a specific pair of

Table 1 Primers used in the amplification of lac and tmr genes from Stenotrophomonas maltophilia isolate TPMD-1

\begin{tabular}{lll}
\hline Primers & Sequences & References \\
\hline LaCF & 5'ATGTCCTTTACCCGTCGA & Verma (2017) \\
LaCR & CAAATGC 3' & Designed for isolation \\
& 5'TCAGACCACCGCAAT & of laccase gene from \\
& CGCGGCCATC 3' & Pseudomonas putida \\
$T m r F$ & 5'GATAGGAGGCATTCA & Jang et al (2005) \\
$T m r R$ & CCTTG 3' & Designed for isolation \\
& 5'AGACTCTATGGATGC & of tmr gene from \\
& GCGCG3' & Citrobacter sp. KCTC \\
& & 186,611 \\
& &
\end{tabular}


primer sets under specific reaction conditions (Table 1). The amplicons obtained were run on $1.2 \%$ agarose gel, also loaded with a 100 bp DNA ladder. The PCR product that was separated corresponded to primers and eluted from the gel using a gel extraction kit (GeNei TM). All amplicons were sequenced and the sequence confirmation was further compared with those in the Gene Bank (http://www.ncbi.nib.gov/blast). The phylogenetic analysis was done to study comparison based on the characterbased maximum likelihood analysis method (MEGA ver. 7.0).

\section{Statistical analysis}

All data are expressed as mean values \pm standard deviation. Comparisons among multiple groups were made with a one-way analysis of variance (ANOVA) followed by Dunnet $t$ test $(P \leq 0.05)$ by using the software PAST 4.03 .

\section{Results}

Isolation and molecular identification of TPM dye discoloring bacteria

Several bacterial isolates were isolated at the thermophilic composting stage of neem oil-seed cake. Among them, six isolates exhibited the ability to decolorize TPM dyes on agar plates, and one of the isolates, strain TPMD-1 was selected for its strong TPM dye decolorizing activity and capable of degrading both the $\mathrm{CV}$ and MG dyes. The bacterial isolate was characterized by its non-motile, gram-negative rods and expressing catalase activity. The $16 \mathrm{~S}$ rRNA sequences were deposited in Gene Bank (accession no. MN830183) and the sequences matched with that of the isolate TPMD-1 cited in the Gene Bank were done. The phylogenetic tree was (Fig. 1) constructed based on the sequence data by the neighbor-joining method, which indicated that the isolate TPMD-1 was closest to Stenotrophomonas maltophilia strain QS3 with 96\% similarity.

\section{Kinetics of CV and MG dye transformation}

The experimental data showed a good fit for the firstorder kinetic model suggesting that the decolorization process depended on the concentration of the dye (Table 2). The low dye concentration (100-200 $\mathrm{mg} \mathrm{L}^{-1}$ ) has a short half-life coupled with large decay constants in both dyes. The MG dye decolorization was significant $(P \leq 0.005)$ with a shorter half-life than the $C V$.

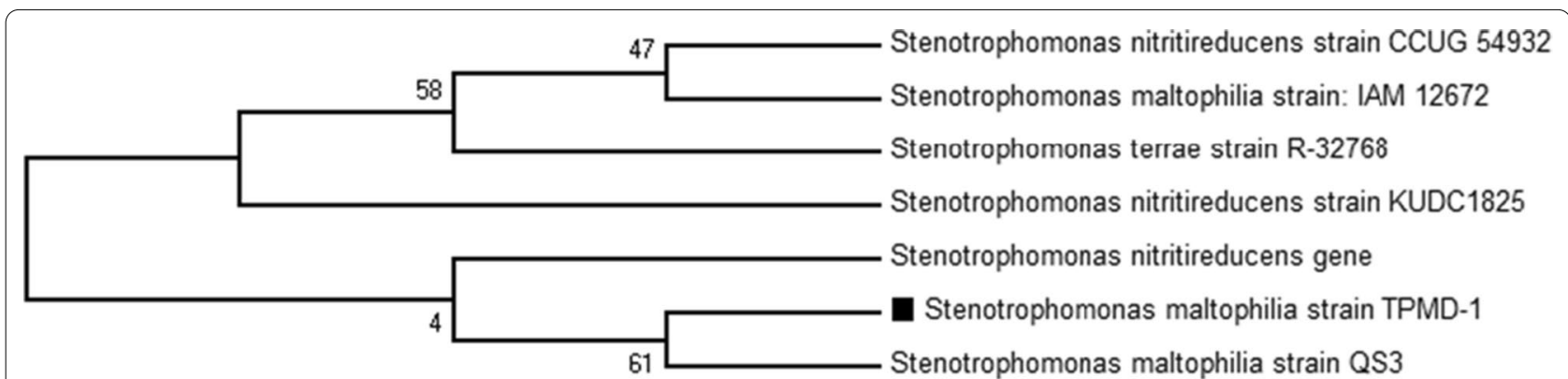

Fig. 1 Phylogenetic distribution of isolate TPMD-1 in comparison to those from NCBI database by neighbor-joining analysis based on their $16 \mathrm{~S}$ rRNA gene sequences

Table 2 Degree, dye removal rate and half-life period of decolorization of melachite green (MG) and crystal violet (CV) by Stenotrophomonas maltophilia isolate TPMD-1

\begin{tabular}{|c|c|c|c|c|c|c|}
\hline \multirow{2}{*}{$\begin{array}{l}\text { Concentration (mg } \\
\mathrm{L}^{-1} \text { ) }\end{array}$} & \multicolumn{3}{|l|}{ MG } & \multicolumn{3}{|l|}{ CV } \\
\hline & $\begin{array}{l}\text { Degree } \\
\text { ofdecolorization (\%) }\end{array}$ & $\lambda\left(\mathrm{h}^{-1}\right)$ & $t_{1 / 2}(h)$ & $\begin{array}{l}\text { Degree of } \\
\text { decolorization (\%) }\end{array}$ & $\lambda\left(\mathrm{h}^{-1}\right)$ & $t_{1 / 2}(\mathrm{~h})$ \\
\hline 100 & $99.46 \pm 0.50^{\mathrm{a}}$ & $0.049 \pm 0.003^{A}$ & $14.14 \pm 0.1^{p}$ & $99.04 \pm 0.65^{\mathrm{a}}$ & $0.04 \pm 0.02^{\mathrm{A}}$ & $17.32 \pm 0.12^{p}$ \\
\hline 200 & $98.24 \pm 0.57^{\mathrm{a}}$ & $0.031 \pm 0.002^{B}$ & $22.35 \pm 0.13^{q}$ & $97.50 \pm 0.54^{b}$ & $0.023 \pm 0.03^{\jmath}$ & $30.13 \pm 0.11^{q}$ \\
\hline 300 & $85.9 \pm 0.53^{b}$ & $0.014 \pm 0.004^{C}$ & $49.51 \pm 0.09^{r}$ & $81 \pm 0.5^{c}$ & $0.010 \pm 0.05^{C}$ & $69.3 \pm 0.10^{s}$ \\
\hline 400 & $79.5 \pm 0.55^{d}$ & $0.012 \pm 0.003^{D}$ & $57.76 \pm 0.1^{r}$ & $75 \pm 0.43^{e}$ & $0.006 \pm 0.03^{\mathrm{E}}$ & $115.5 \pm 0.09^{t}$ \\
\hline 500 & $67.4 \pm 0.51^{f}$ & $0.009 \pm 0.004^{F}$ & $77.01 \pm 0.13^{u}$ & $54.51 \pm 0.47^{g}$ & $0.003 \pm 0.03^{\mathrm{G}}$ & $231 \pm 0.11^{v}$ \\
\hline
\end{tabular}

Mean values \pm SD followed by different letters in same column indicate significant differences according to DMRT $(P<0.05)$

'a-g' was used to compare degree of decolorization of both dyes, 'A-G' used to compare rate constants, and $p-v$ to compare half-life periods of two dyes 


\section{Effect of physical parameters on MG decolorization}

The temperature treatments affected the decolorization activity (non-significant) of $S$. maltophilia TPMD-1 (Table 3). In contrast, $\mathrm{pH}$ caused a significant $(P \leq 0.005)$ difference in decolorization activities. The decolorizing ability of the isolate was also affected under static $(0 \mathrm{rpm})$ and constant shaking at 100 and $150 \mathrm{rpm}$. The optimum decolorization activity was reported at pH 6 to 7 at $28-30{ }^{\circ} \mathrm{C}$; under this condition, the shaking did not affect discoloration (either 100 or $150 \mathrm{rpm}$ ). An increase in $\mathrm{pH}$ to 8 and temperature to $35{ }^{\circ} \mathrm{C}$ reduced the decolorization efficiency, but an increase in agitation speed $(150 \mathrm{rpm})$ caused a slight improvement.

\section{Biotransformation analysis}

The HPLC chromatogram of control (without bacterial treatment- $0 \mathrm{~h}$ ) contained three significant peaks at the retention time of $8.26,8.812$ and $11.85 \mathrm{~min}$. The chromatogram of the bacterial treatment sample had significant peaks at $6.91,7.31$ and $8.92 \mathrm{~min}$ (Fig. 2). The FTIR spectrum of control MG $(0 \mathrm{~h})$ contains distinct peaks in the fingerprint region $\left(1500-500 \mathrm{~cm}^{-1}\right)$, which corresponded to mono- and para-substituted

Table 3 Effect of $\mathrm{pH}$, temperature and rate of agitation on decolorization (\%) of MG by Stenotrophomonas maltophilia isolate TPMD-1

\begin{tabular}{|c|c|c|c|c|c|c|}
\hline \multirow[t]{3}{*}{$\mathrm{PH}$} & \multicolumn{6}{|c|}{ Temperature/agitation rate } \\
\hline & \multicolumn{2}{|l|}{$28^{\circ} \mathrm{C}$} & \multicolumn{2}{|l|}{$30^{\circ} \mathrm{C}$} & \multicolumn{2}{|l|}{$35^{\circ} \mathrm{C}$} \\
\hline & 100 rpm & $150 \mathrm{rpm}$ & 100 rpm & 150 rpm & $100 \mathrm{rpm}$ & $150 \mathrm{rpm}$ \\
\hline 6 & $98.33 \pm 0.5^{\mathrm{A}}$ & $98.66 \pm 0.6^{a}$ & $97.86 \pm 0.43^{\mathrm{A}}$ & $98.58 \pm 0.53^{\mathrm{a}}$ & $97.80 \pm 0.45^{\mathrm{A}}$ & $98.22 \pm 0.45^{a}$ \\
\hline 7 & $97.39 \pm 0.6^{\mathrm{B}}$ & $98.21 \pm 0.51^{b}$ & $97.16 \pm 0.53^{\mathrm{A}}$ & $97.64 \pm 0.57^{b}$ & $97.12 \pm 0.52^{\mathrm{A}}$ & $98.01 \pm 0.5^{\mathrm{a}}$ \\
\hline 8 & $90.04 \pm 0.62^{c}$ & $96.77 \pm 0.62^{c}$ & $89.35 \pm 0.3^{B}$ & $91.14 \pm 0.42^{c}$ & $84.17 \pm 0.6^{\mathrm{B}}$ & $89.86 \pm 0.67^{b}$ \\
\hline
\end{tabular}

The mean $\pm S D$ values in a column followed by different letters are significantly different (LSD $P \leq 0.01)$

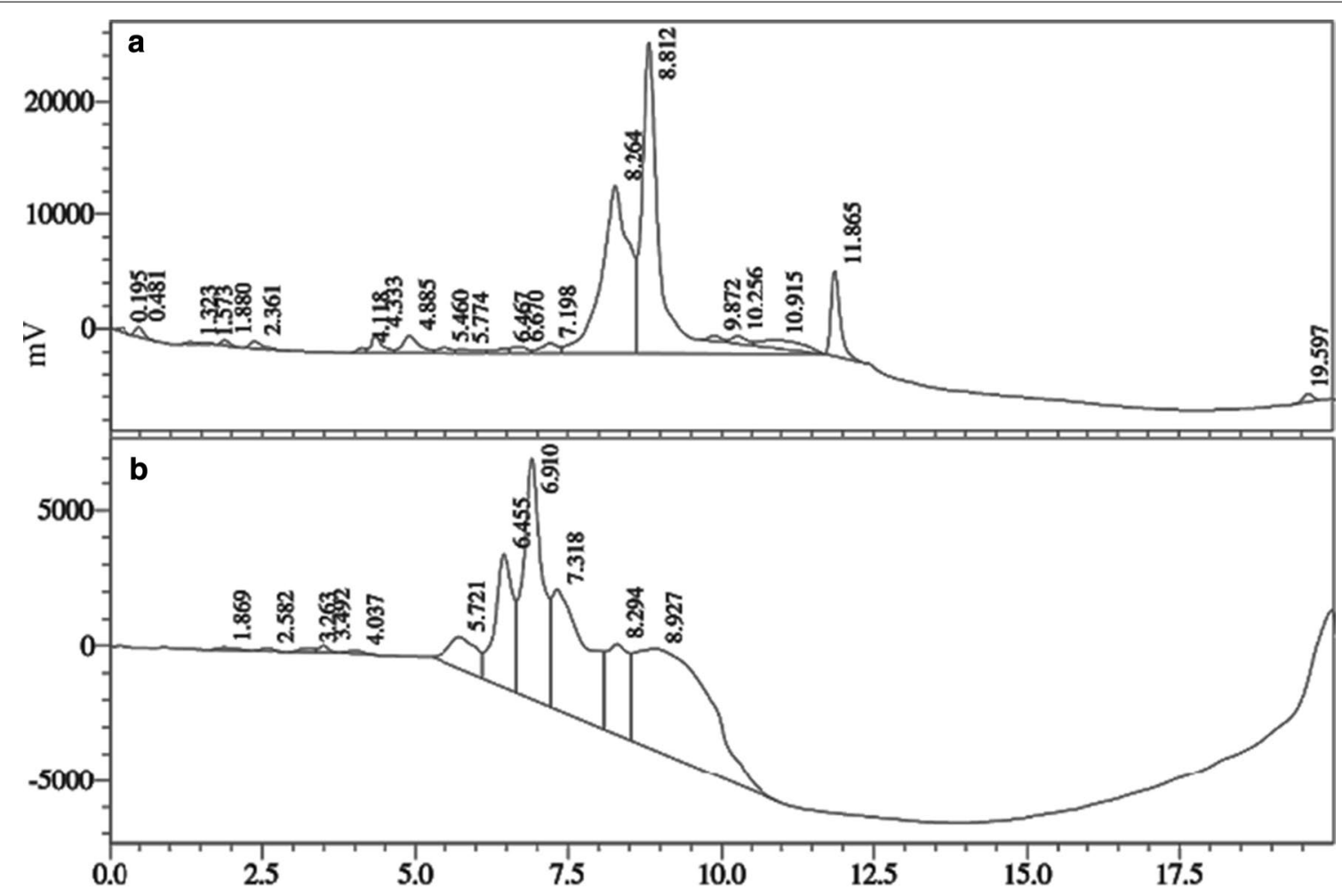

Time ( $\min )$

Fig. 2 HPLC chromatogram of malachite green a Control ( $0 \mathrm{~h}$ ) and b MG treated with bacterial isolate TPMD-1 (24 h) 
benzene rings that were characteristic of MG. The peaks at $829.76 \mathrm{~cm}^{-1}$ for $\mathrm{C}=\mathrm{C}$ trisubstituted benzene ring, $1503.45 \mathrm{~cm}^{-1}$ for $\mathrm{N}-\mathrm{O}$ stretching nitro compounds, $1768 \mathrm{~cm}^{-1}$ for $\mathrm{C}-\mathrm{H}$ bending aromatic ring, $3027.58 \mathrm{~cm}^{-1}$ and $3645.06 \mathrm{~cm}^{-1}$ for $\mathrm{O}-\mathrm{H}$ stretch that are typical peaks of MG were also observed in this study (Fig. 3). The broad peak observed in the region of 3010 to $3850 \mathrm{~cm}^{-1}$ for control which corresponded with $\mathrm{N}-\mathrm{H}$ stretching vibration of primary amines, was absent in the spectrum of the bacterial treated product (Fig. 3). The peaks at 3027.58 indicated the $\mathrm{C}-\mathrm{H}$ stretching vibrations, and its corresponding bending with aromatic ring vibration occurred at $1768.36 \mathrm{~cm}^{-1}$. The shifting of the peak from 1643.14 to $1768.36 \mathrm{~cm}^{-1}$ showed changes in the aromatic ring structure by bacteria treated sample.

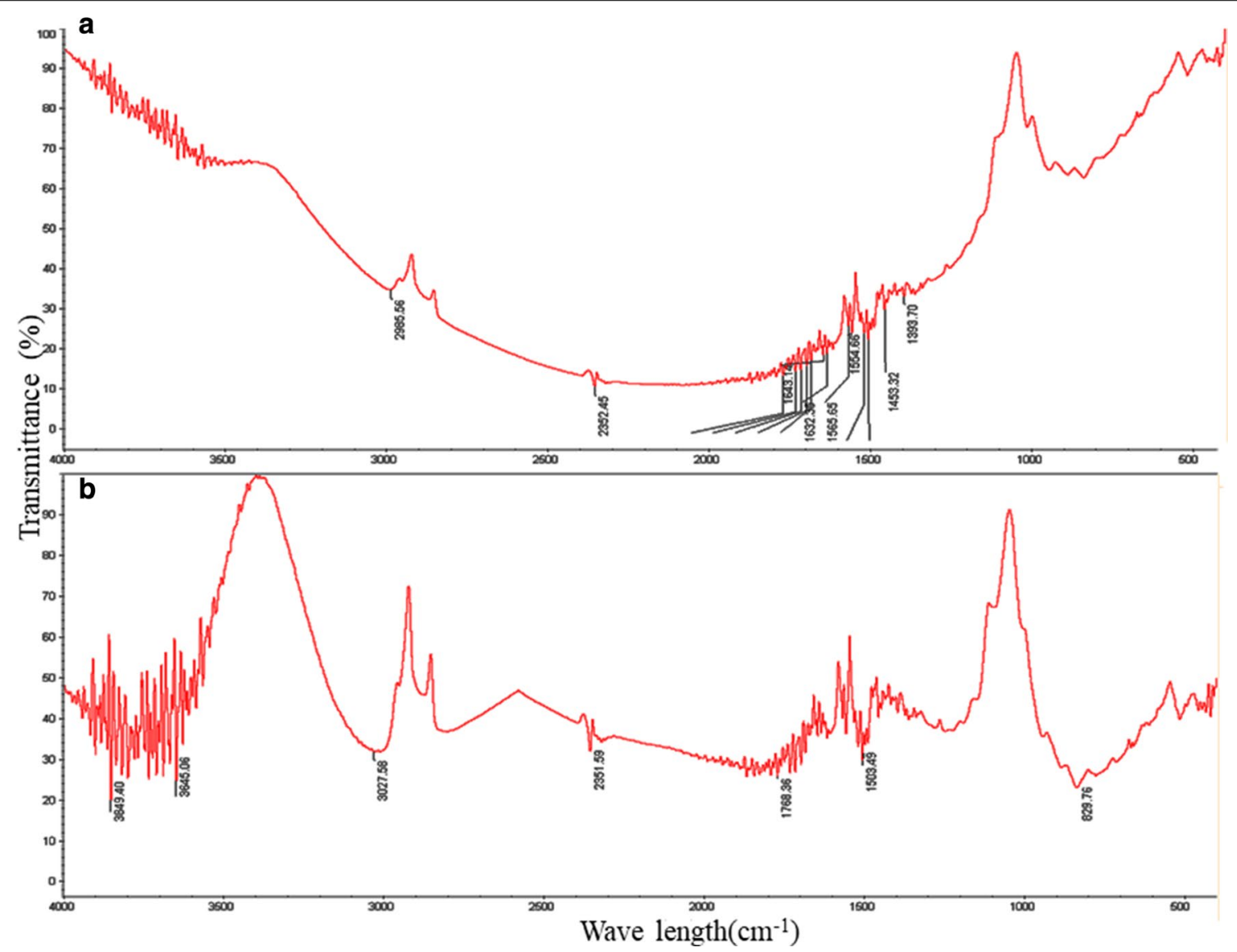

Fig. 3 FTIR spectra of a Control ( $\mathrm{h}$, only basal salt medium $+M G$ ) and $\mathbf{b}$ treatment $(24 \mathrm{~h}$, basal salt medium $+M G+$ bacterial isolate TPMD-1)

Table 4 Evaluation of phytotoxicity of MG and degraded product on seed germination and seedling length of Sorghum vulgare and Eleusine coracana

\begin{tabular}{|c|c|c|c|c|c|c|}
\hline \multirow[t]{2}{*}{ Treatments } & \multicolumn{3}{|l|}{ Sorghum vulgare } & \multicolumn{3}{|l|}{ Eleusine coracana } \\
\hline & Germination (\%) & Shoot length (mm) & Root length (mm) & Germination (\%) & Shoot length (mm) & $\begin{array}{l}\text { Root length } \\
(\mathrm{mm})\end{array}$ \\
\hline Water & $100 \pm 0.7^{a}$ & $5.5 \pm 0.40^{d}$ & $3.2 \pm 0.25^{9}$ & $100 \pm 0.6^{A}$ & $5.4 \pm 0.4^{\mathrm{D}}$ & $3.4 \pm 0.3^{G}$ \\
\hline Control (MG) & $30 \pm 0.65^{b}$ & $1.5 \pm 0.52^{\mathrm{e}}$ & $0.8 \pm 0.1^{h}$ & $40 \pm 0.7^{B}$ & $1.8 \pm 0.45^{\mathrm{E}}$ & $0.7 \pm 0.15^{\mathrm{H}}$ \\
\hline $\begin{array}{l}\text { Treatment } \\
\text { (MG + bac- } \\
\text { teria) }\end{array}$ & $85 \pm 0.58^{c}$ & $4.5 \pm 0.43^{f}$ & $2.8 \pm 0.25^{i}$ & $90 \pm 0.5^{c}$ & $3.8 \pm 0.3^{F}$ & $1.5 \pm 0.31^{1}$ \\
\hline
\end{tabular}




\section{Phytotoxicity}

Malachite green is phytotoxic to both seedlings of Sorghum vulgare and Eleusine coracana when treated to seeds (Table 4$)$. The significantly $(P \leq 0.05)$ reduced seed germination and radicle and plumule length. On the other hand, the degraded metabolites of MG did not affect seed germination (Table 4), indicating the reduction in toxicity of metabolites as compared to that of MG in control.

\section{Molecular snapshot of bacterial isolate for 'lac' and ' $t m r^{\prime}$ genes \\ Analysis of the lac and tmr gene}

This gene was identified in S. maltophilia TPMD-1 with the aid of the already designed primers specific for the 'lac' gene (Table 1). The PCR reaction resulted in the amplification of two homologous amplicons of $800 \mathrm{bp}$ (lac 1) and $600 \mathrm{bp}$ (lac 2) with fragments of the 'lac' gene (Fig. 4). Further, each band of partial laccase gene was sequenced and analyzed with the corresponding gene sequences documented in the Gene Bank database (http://www.ncbi.nlm.nih.gov/blast). The sequence analysis revealed that the laccase gene of $S$. maltophilia isolates TPMD-1 had 97\% homology of large amplicon
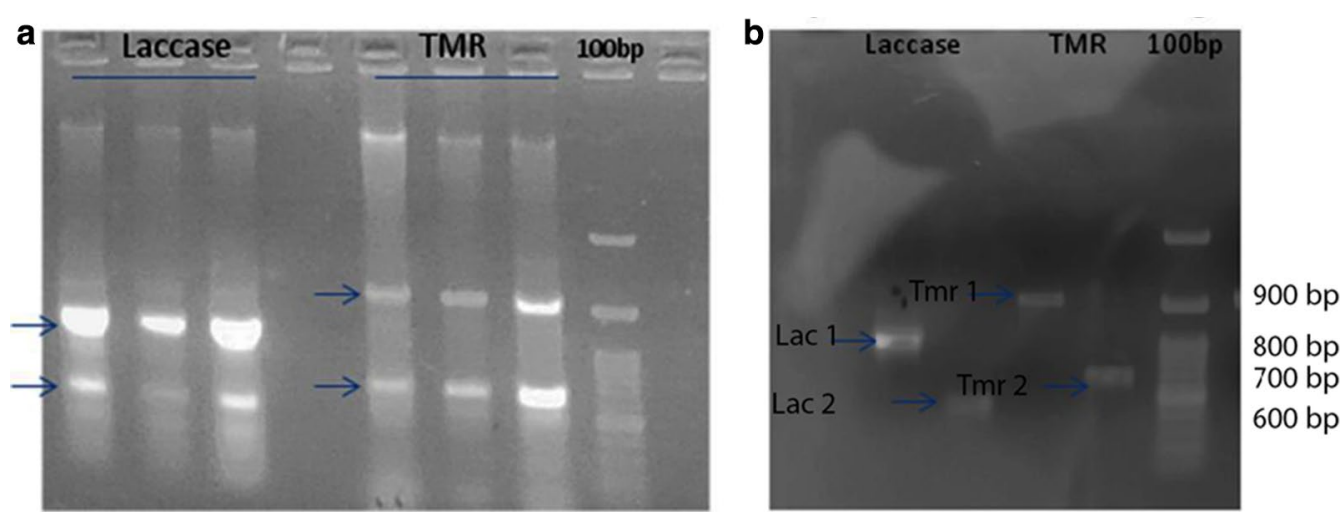

Fig. 4 Agarose gel electrophoresis (1.2\% w/V) of laccase (L1 and L2) and TMR (T1 and T2) gene fragments of Stenotrophomonas matophilia TPMD-1 amplified by PCR $\mathbf{a}$ pre-purified and $\mathbf{b}$ purified laccase and TMR genes (100 bp DNA ladder at the extreme right lane)

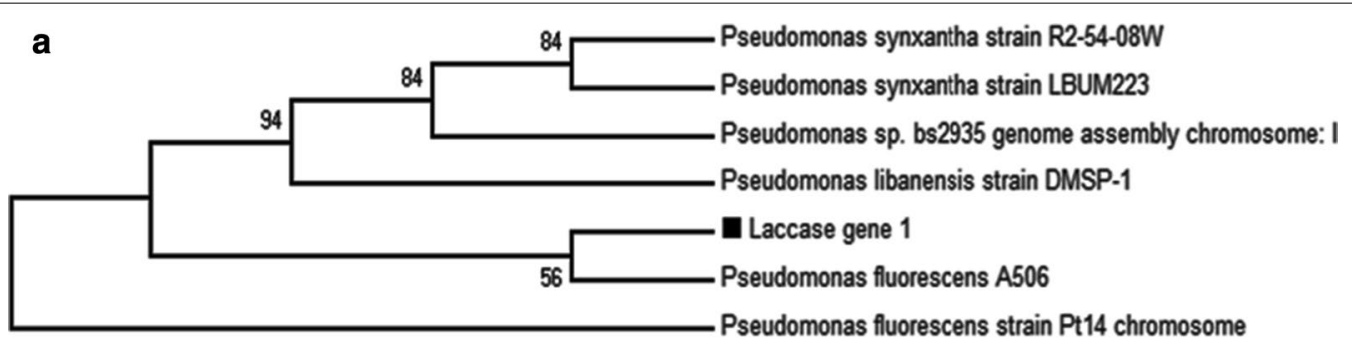

b

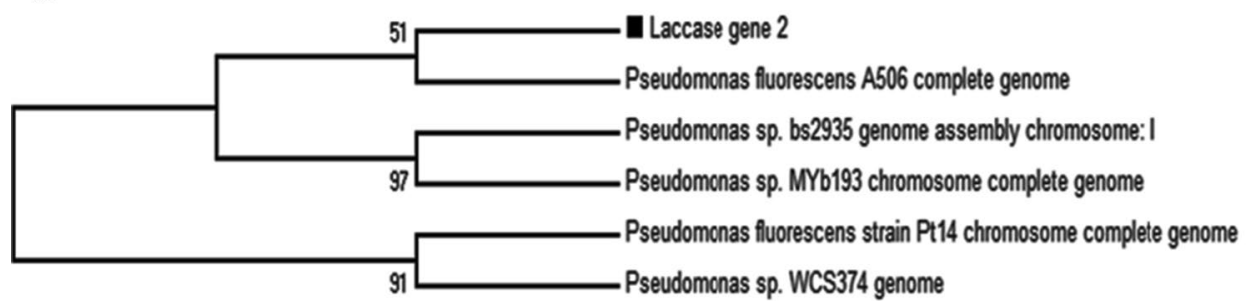

Fig. 5 Phylogenetic representation of $\mathbf{a}$ Laccase 1 and $\mathbf{b}$ Laccase 2, amplicons of S.maltophilia TPMD-1 in comparison to those from NCBI database by maximum likelihood analysis based on laccase specific primers 
(800 bp) and $98 \%$ of small amplicon (600 bp) with Pseudomonas fluorescence A506 complete chromosome (Fig. 5).

The PCR was performed to determine the presence of gene tmr in the genomic DNA of MG dye discoloring Stenotrophomonas sp. In this study, two homologous amplicons of $900 \mathrm{bp}$ (Tmr 1) and $700 \mathrm{bp}$ (Tmr 2), obtained from S. maltophilia isolate TPMD-1 (Fig. 4), were sequenced and compared with those of the related genes available in Gene Bank (NCBI BLAST tool). The large amplified gene 'tmr' sequence with 900 bp showed 97.28\% identity with Pseudomonas sp., while a small one 700 bp with $83 \%$ identity showed similarity with Stenotrophomonas sp. Based on this, the phylogenetic tree was constructed (Fig. 6).

\section{Discussion}

Literature survey indicated that several bacterial strains had been involved in the decolorization of MG and CV (Sneha et al. 2014; Chaturvedi and Verma 2015; Wanyonyi et al. 2017). In the previous study, Kim et al. (2008) isolated the S. maltophilia LK-24, which was found to decolor crystal violet, a TPM dye. An isolate of $S$. maltophilia capable of discoloring both CV and MG dyes is not documented in the literature. Hence this is the first report of the strain of S. maltophilia TPMD-1 that degrades both the MG and CV dyes. In other studies, $S$. maltophilia was used in the bioremediation of hydrocarbons (Liu et al. 2007; Urszula et al. 2009; Gao et al. 2013) and chlorinated pesticides (Dubey and Fulekar 2012) and the decolorization of certain synthetic dyes such as methylene blue, toluidine blue, methyl green, indigo blue, neutral red, congo red, methyl orange, and reactive pink, golden yellow MR (Galai et al. 2009; Rajeswari et al. 2015). In addition to the above, strains of Stenotrophomonas sp, particularly S. maltophilia that are also reported to be resistant to heavy metals (Zhang et al. 2001; Crossman et al. 2008) are shown to produce biofilm with a great level of exopolysaccharide and protein that enabled the bacteria to grow in the presence of toxic heavy metals (Crossman et al. 2008; Ryan et al. 2009). Some strains also adapted to grow in the industrial effluents containing both dyes and heavy metals. Furthermore, in vitro shaking condition induced S. maltophilia to produce laccase in the presence of copper and decolorize methyl blue, toluidine blue, methyl green, methyl orange, congo red, and pink (Galai et al. 2009, 2012).

Several authors documented that the decolorization of synthetic dyes follows the first-order decay model (Mutafov et al. 2006; Van der Zee et al. 2001; Selvakumar et al. 2013). The present study adopted this model to explain the rate of decolorization of $\mathrm{CV}$ and MG by $S$. maltophilia TPMD-1. This model simplifies the information of the physiology of the dye decolorization process and helps in interpreting the experimental results based on the comparison of numerical values. The comparison of coefficients of the model obtained for the bacterial isolate revealed a significant difference between the decolorization of MG and CV. The factors of the study included an initial concentration of $\mathrm{CV}$ and $\mathrm{MG}$ and an incubation period in the liquid medium. This difference in decolorization efficiencies of two compounds could be assigned
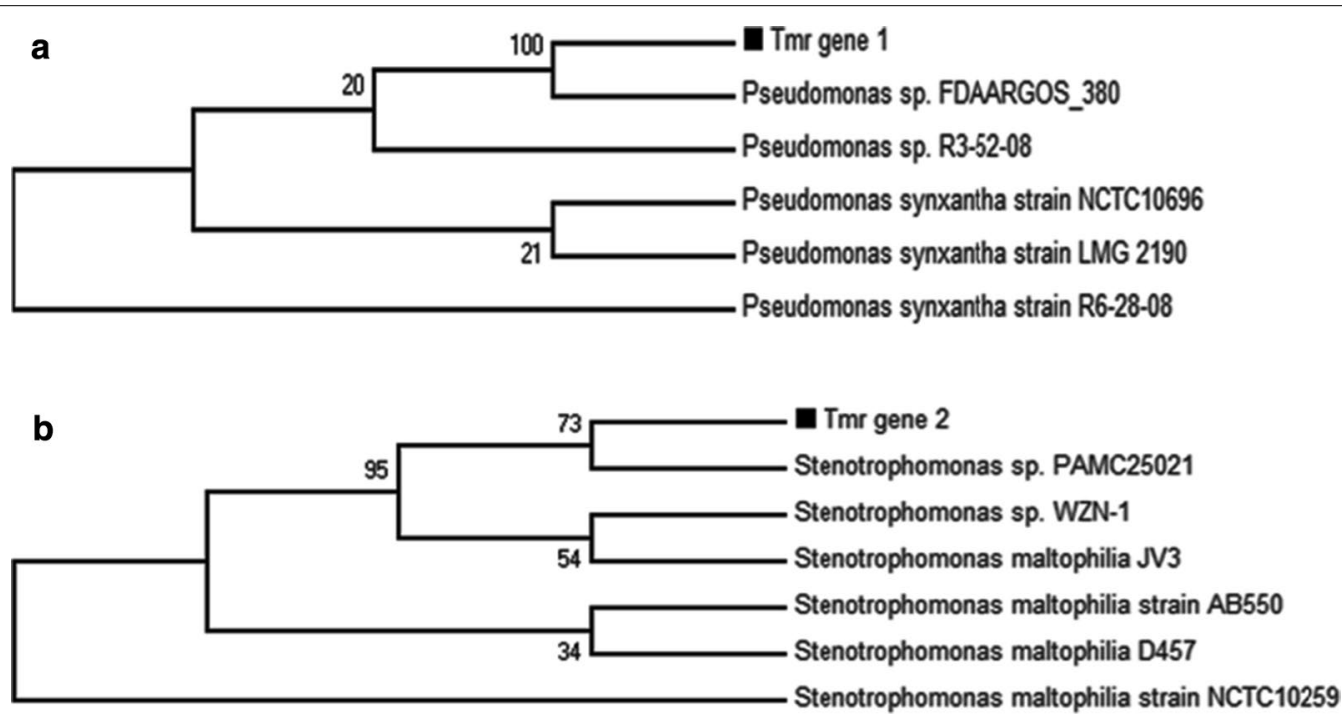

Fig. 6 Phylogenetic representation of a TMR 1 and $\mathbf{b}$ TMR 2, amplicons of S.maltophilia TPMD-1 in comparison to those from NCBI database by maximum likelihood analysis based on TMR specific primers 
to different chemical structures, wherein MG consists of two dimethyl groups in two side chains while CV consists of three dimethyl groups in three side chains (Rajesh and Uttam, 1999). Similar observations were made, Wang et al. (2011) in the decolorization experiment on MG and CV by Achromobacter xylosoxidans MG1. Hence, MG with a short half-life was selected for further investigations. The process of dye degradation is shown to depend on the physicochemical status of the decolorization environment. The MG dye decolorization efficiency was very low in a static condition at different temperature and $\mathrm{pH}$ range. This is evident for the oxygen requirement of the organism to decolorize the dye since isolate is catalasepositive and aerobic (Assih et al. 2002). The previous study also reported the importance of shaking or oxygen in the bacterial discoloration of different dyes, including methyl orange, congo red and malachite green (Pradhan et al. 2012). The anaerobic and aerobic conditions influence enzyme-related dye degradation (Khan et al. 2012) and hence, the agitation could be playing an essential role in increasing the availability of oxygen in the liquid medium, thus stimulating the discoloration ability, particularly at alkaline $\mathrm{pH}$ (Table 3 ). However, the requirement of static condition for MG decolorization is also documented (Chaturvedi and Verma 2015) suggesting the ambiguity in the understanding of the decolorization mechanism. The present study indicated that the acidic $\mathrm{pH}$ and low temperature could influence the bacterial isolate TPMD- 1 as compared to the alkaline $\mathrm{pH}$ and temperature $>35{ }^{\circ} \mathrm{C}$. In this context, the acidic textile industrial effluents (Zouch et al. 2018) could be supporting the adaptation of the bacteria resulting in dye decolorization.

In the biological system, decolorization of MG occurs by two processes-absorption or adsorption of the dye by bacterial/fungal cells and degradation. During this process, the intensity of the dye in the medium decreases over time. Hence, HPLC could be a valuable technique to differentiate between these two processes. The disappearance of specific peaks with the concomitant appearance of individual new peaks was observed. This peak corresponded to various metabolites that are produced during the degradation of MG. The characteristic presence of new peaks or the absence of any peak after incubation was attributed to the production of new by-products by growing cells (Chen et al. 2008; Dhanve et al. 2009). One of the limitations of HPLC was the lack of deterministic data to confirm the categories of those substances. The biotransformation of MG dye was confirmed by comparing the FTIR analysis of untreated control with the treated sample. The prominent peak at $829.76 \mathrm{~cm}^{-1}$ representing mono or para-substituted benzene ring $(\mathrm{C}-\mathrm{H}$ bending vibration $850-670 \mathrm{~cm}^{-1}$ ) (Coates 2000), which is prominent in control, is absent in bacterial treatment.
Such observation was also made in Ochrobactrum pseudogrignonense strain GGUPV1 and laccase producing Bacillus thuringensis RUN1 grown in MG containing media (Khan et al. 2012; Chaturvedi and Verma 2015). The previous reports also documented the presence of benzene ring, $\mathrm{C}-\mathrm{H}$ and $\mathrm{O}-\mathrm{H}$ stretching aromatic rings with nitro compounds in the MG controls (Cheriaa et al. 2012; Vijayalakshmidevi and Muthukumar, 2014). Degradation of aromatic structures was supported by the absence of peaks below $1000 \mathrm{~cm}^{-1}$ (Vijayalakshmidevi and Muthukumar, 2014). The decreased peak intensity in the fingerprint region could be attributed to the production of a degraded metabolite of MG. Parshetti et al. 2006 opines that the variations in the FTIR spectra of bacterial treatment in comparison to MG (control) indicated biotransformation. The bacterial decolorization of MG involves a series of reactions such as $\mathrm{N}$-demethylation, reduction, benzene removal, and oxidation (Wang et al. 2012). This resulted in the formation of methanone [4- (dimethylamino)], phenyl phenyl ( $\mathrm{m} / \mathrm{z}$ 148) and phenol, 3-(dimethylamino) (m/z 136), phosphinic acid, [p-dimethyl amino)phenyl], methyl ester $(\mathrm{m} / \mathrm{z} 318)$, (E)-2- hydroxy-4 diethylamino-stilbene $(\mathrm{m} / \mathrm{z} 239)$ and Benzylaniline $9 \mathrm{~m} / \mathrm{z} 183$ ) (Chaturvedi and Verma 2015; Wanyonyi et al. 2017). The HPLC and FTIR analyses of the present study indicated that the decolorization of MG occurred through degradation and not by cellular adsorption, following changes in the molecular orientation of the pure dye molecule; and the resulted in the formation of fragments as indicated by the formation of new peaks in HPLC and FTIR spectra. Moreover, the colorless microbial biomass after complete decolorization confirmed the dye biodegradation ability of bacterial cells.

The MG and its reduced forms are equally phytotoxic (Culp and Beland, 1996). The toxicity of MG and its degraded products are a primary environmental concern, since they are disposed-of into water bodies without any treatment, and these products find entry to the irrigation system and finally, the cultivation fields and portable water system. The phytotoxicity of MG and its degraded products was determined in sorghum and finger millet seedlings. The findings of this study are consistent with those of the previous reports that MG is toxic to plants, while its degraded products are less toxic (Gomare et al. 2009; Chaturvedi and Verma 2015).

\section{Molecular snapshot of bacterial isolate for 'lac' and 'tmr' genes}

Laccases (p-benzenediol: oxygen oxidoreductase EC1.10.3.2) are the member of a multicopper protein family, belonging to a group of blue copper protein, and are widely produced in plants, fungi and bacteria (Shraddha et al. 2011). However, bacterial laccase activity has 
been more profound than its fungal counterpart (Feng et al. 2015). The bacterial species like Bacillus halodurans, B. subtilis SF, B. pumilus, Azospirillum lipoferum, Pseudomonas desmolyticum NCIM 2112, P. putida have been reported for laccase production (Narayanan and Murugan, 2014). The gene 'lac' codes for the laccase, which is previously known as the MG degrader (Yang et al. 2014). The bacterial laccase enzyme is both intra or extracellular (Muthukumarasamy et al. 2015; Dhiman and Shirkot 2015) capable of oxidizing various benzene ring containing compounds (phenols and polyphenols) and plays a vital role in the detoxification of textile effluents and bioremediation process (Couto and Herrera 2006; Chadra and Chowdhary 2015). The oxidation could be attributed to four copper atoms in laccase that, play an essential role in the enzyme catalytic mechanisms (Cha and Cooksey 1991). Various bacterial laccases have been isolated and studied at the molecular level, and laccase production is optimized in bacteria for dye degradation (Couto and Herrera, 2006; Feng et al 2015; Kuppusamy et al. 2017). Unuofin et al. (2019) opine that the exact function of all the bacterial laccase genes discovered so far has not been ascertained; however, they have been linked with resistance to radiation and synthesis of pigments. There is a connection between laccase activity induction and bacterial dye decolorization (Lee et al. 1994; Ayed et al. 2010; Unuofin 2020). The earlier report is available related to the copper depended on an enzyme, multicopper oxidase in Stenotrophomonas maltophilia coded by cop $A$ gene which has laccase activity, copper resistance and in vitro dye decolorization property (Galai et al. 2011). Similarly, the laccase enzyme from S. maltophilia AAP56 is metal-dependent $\left(\mathrm{Cu}^{2+}\right)$ and copper sulfate stimulates the laccase production and bacteria can decolorize the synthetic dye in shaking conditions (Galai et al. 2009).

A previous study of bacterial biodegradation of MG indicated that the $t m r$ gene product was responsible for dye degradation (Wang et al. 2012; Jang et al. 2005). This enzyme can convert the MG into its leuco form (Jang et al. 2005). This is true in Pseudomonas sp containing $t m r 2$ gene, which is responsible for discoloration of the TPM dyes including MG, CV and Basic Fuchsin ( $\mathrm{Li}$ et al. 2009). However, the most efficient TMR substrate appeared to be malachite green because it exhibited favorable structural features when modeled with the ternary complex (Jang et al. 2005). Gene homologs similar to the above were also documented in Achromobacter xylosoxidans MG1 and Exiguobacterium sp. MG2 and the ' $t m r$ ' gene was amplified in the present study by using similar primers. Similar, observations were also made for Citrobacter sp, which is previously known for MG degradation (Wang et al. 2011, 2012). The engineered freshwater cyanobacteria Synchococcus containing triphenylmethane reductase gene 'katmr' was shown to produce a soluble recombinant protein that degraded malachite green into small molecules 4-methylaminobenzoic acid and 4-hydroxyl-aniline and that are nontoxic to wheat seeds (Han et al. 2020). Huan-Mei et al. 2011 opined that 'tmr' gene could have been horizontally transferred from Pseudomonas sp. strain $\mathrm{K}_{9}$ to another MG degrading Pseudomonas sp. strain MDB-1, based on the relatedness of 'tmr' gene and the associated protein product.

The presence of pair of homologs lac and $t m r$ genes indicating the gene duplication. This kind of gene duplication and large amplifications that generated several replicons of the same gene within a single bacterium is a common phenomenon. Such gene duplications could have been maintained in the long-term during evolution to increase the number of gene products (Francino 2012). This could be the possible reason behind the presence of multiple laccase genes detected in both fungi and bacteria. The findings of Sakamoto et al. (2015) that distinct multi-copper oxidase genes are present in Lentinula edodes supported the above observation. Recently, Unuofin et al. (2019) also identified the five different homologous laccase gene sequences in Achromobacter xylosoxidans and Citrobacter freundii. This homology suggested that the laccase gene of $S$. maltophilia TPMD-1 performs a similar function.

\section{Conclusion}

The TPM dyes like MG and CV are the most commonly used dyes industrially, which is the cause of concern for the pollution of water bodies. A bacterial strain $S$. maltopholia isolate TPMD-1 obtained from the compost of neem oil-cake was efficiently degraded to both MG and CV. The MG degradation rate was slightly more in neutral $\mathrm{pH}$ at $28-30{ }^{\circ} \mathrm{C}$. The Stenotrophomonas maltophilia TPMD-1 contained TMR and laccase genes that were previously considered as efficient enzymes in the decolorization of MG. Furthermore, the widely distributed bacterium Stenotrophomonas maltophilia is saprophytic and has the highest efficiency in the decolorization of MG. This study helps future understanding of the complete biodegradation mechanism of MG or other triphenylmethane dyes with a similar structure.

\section{Abbreviations}

MG: Malachite Green; RNA: Ribose nucleic acid; TPMD: Triphenyl methane degrading; TPM: Triphenyl methane; HPLC: High-Performance Liquid Chromatography; FTIR: Fourier Transform Infrared Spectroscopy; TMR: Triphenyl methane reductase; NADH: Nicotinamide adenine dinucleotide; Lac: Laccase; PCR: Polymerase Chain reaction; NCBI: National Center for Biotechnology Information; BLAST: Basic Local Alignment Search Tool; DNA: Deoxyribonucleic Acid; ANOVA: Analysis of variance; $\mathrm{KH}_{2} \mathrm{PO}_{4}$ : Potassium dihydrogen phosphate; 
$\mathrm{ZnSO}_{4}$ : Zinc Sulfate; $\mathrm{K}_{2} \mathrm{HPO}_{4}$ : Dipotassium phosphate; $\mathrm{FeSO}_{4}$ : Ferrous sulfate; $\mathrm{MnSO}_{4}$ : Manganese sulfate; $\mathrm{MgSO}_{4}$ : Magnesium sulfate; $\mathrm{Na}_{2} \mathrm{SO}_{4}$ : Sodium sulfate; KBr: Potassium bromide.

\section{Acknowledgements}

Not applicable.

\section{Authors' contributions}

VUA collection of neem oil-seed cakes, isolate the composting and dye degrading bacterium and conducted the molecular experiments and preparation of manuscript. MBS designed the methodology revision of manuscript. $B G, R K K$ and EN provide laboratory facility and revised the manuscript and All authors have read and approved the manuscript.

\section{Funding}

The research work was supported by the Department of Science and Technology under the INSPIRE scheme, with Grant No IF150337 New Delhi, India.

\section{Availability of data and materials}

All data generated or analysed during this study are included in this article.

\section{Declarations}

\section{Ethics approval and consent to participate}

Not applicable.

\section{Consent for publication}

Not applicable.

\section{Competing interests}

The authors declare that they have no competing interests.

\section{Author details}

'Department of PG Studies and Research in Applied Botany, Jnana Sahyadri, Kuvempu University, Shimoga Dist., Shankaraghatta 577 451, India. ${ }^{2}$ Department of Forestry and Environmental Science, University of Agricultural Sciences, GKVK Campus, Bangalore 560065, India. ${ }^{3}$ Department of Agricultural Microbiology, University of Agricultural Sciences, GKVK Campus, Bangalore 560065, India.

Received: 11 November 2020 Accepted: 3 March 2021

Published online: 26 April 2021

\section{References}

Ali H, Ahmed W, Haq T (2009) Decolorization and degradation of malachite green by Aspergillus flavus and Alternaria solani. Afr J Biotechnol 8:1574-1576

Assih EA, Ouattara AS, Thierry S, Cayol J, Labat M, Macarie H (2002) Stenotrophomonas acidaminiphila sp. nov., a strictly aerobic bacterium isolated from an upflow anaerobic sludge blanket (UASB) reactor. Int J Syst Evol Microbiol 52:559-568. https://doi.org/10.1099/ijs.0.01869-0

Ayed L, Khelifi E, BenJannet H, Miladi H, Cheref A, Achour S, Bakhrouf A (2010) Response surface methodology for decolorization of azo dye Methyl Orange by bacterial consortium: Produced enzymes and metabolites characterization. Chem Eng J 165:200-208

Carliell CM, Barclay SJ, Shaw C, Wheatley AD, Buckley CA (1998) The effect of salts used in textile dyeing on microbial decolorization of a reactive azo dye. Environ Technol 19:1133-1137. https://doi.org/10.1080/0959333190 8616772

Cha J, Cooksey DA (1991) Copper resistance in Pseudomonas syringae by periplasmic and outer membrane proteins. Proc Natl Acad Sci USA 88:8915-8919

Chandra R, Chowdhary P (2015) Properties of bacterial laccases and their application in bioremediation of industrial wastes. Environ Sci Process Impacts 17:326-342. https://doi.org/10.1039/c4em00627e

Chaturvedi V, Verma P (2015) Biodegradation of malachite green by a novel copper tolerant Ochrobactrum pseudogrignonense strain GGUPV1 isolated from copper mine wastewater. Bioresour Bioprocess 2:42. https://doi.org/ 10.1186/s40643-015-0070-8

Chen CH, Chang CF, Ho CH et al (2008) Biodegradation of crystal violet by a Shewanella sp NTOU1. Chemosphere 72:1712-1720. https://doi.org/10. 1016/j.chemosphere.2008.04.069

Cheriaa J, Khaireddine M, Rouabhia M, Bakhrouf A (2012) Removal of triphenylmethane dyes by bacterial consortium. The Scientific World. https://doi. org/10.1100/2012/512454

Cho HJ, Han J, Park Y (2013) Kaempferol induces cell cycle arrest in HT-29 human colon cancer cells. J Cancer Prevent 18:1-7. https://doi.org/10 15430/JCP.2013.18.3.257

Coates, (2000) Interpretation of infrared spectra. In: Meyers RA (ed) A practical approch, in Encyclopedia of analytical chemistry. Wiley, Chichester, pp 10815-10837

Couto SR, Herrera JLT (2006) Industrial and biotechnological applications of laccases: a review. Biotechnol Adv 24:500-513

Crossman LC, Gould VC, Dow JM et al (2008) The complete genome, comparative and functional analysis of Stenotrophomonas maltophilia reveals an organism heavily shielded by drug resistance determinants. Genome Biol 9:R74. https://doi.org/10.1186/gb-2008-9-4-r74

Culp SJ, Beland FA (1996) Malachite Green: a toxicological review. Int J Toxicol 15:219-238. https://doi.org/10.3109/10915819609008715

Dhanve RS, Kalyani DC, Phugare SS, Jadhav JP (2009) Coordinate action of Exiguobacterial oxidoreductive enzymes in biodegradation of reactive yellow 84A dye. Biodegradation 20:245-255. https://doi.org/10.1007/ s10532-008-9217-z

Dhiman K, Shirkot P (2015) Bioprospecting and molecular characterization of laccase producing bacteria from paper mills of Himachal Pradesh. Proc Natl Acad Sci India Sect B Biol Sci 85:1095-1103. https://doi.org/10.1007/ s40011-015-0541-X

Du LN, Wang S, Li G, Wang B, Jia XM, Zhao YH, Chen YL (2011) Biodegradation of malachite green by Pseudomonas sp. strain DY1 under aerobic condition: characteristics, degradation products, enzyme analysis and phytotoxicity. Ecotoxicology 20:438-446. https://doi.org/10.1007/ s10646-011-0595-3

Dubey KK, Fulekar MH (2012) Chlorpyrifos bioremediation in Pennisetum rhizosphere by a novel potential degrader Stenotrophomonas maltophilia MHF ENV20. World J Microbiol 28:1715-1725. https://doi.org/10.1007/ s11274-011-0982-1

Feng S, Su Y, Dong M et al (2015) Laccase activity is proportional to the abundance of bacterial laccase-like genes in soil from subtropical arable land. World J Microb Biot 31:2039-2045. https://doi.org/10.1007/ s11274-015-1944-9

Francino MP (2012) The ecology of bacterial genes and the survival of the new. Int J Evol Biol 2012:1-14. https://doi.org/10.1155/2012/394026

Galai S, Limam F, Marzouki MN (2009) A new Stenotrophomonas maltophilia strain producing laccase use in decolorization of synthetics dyes. Biotechnol Appl Bioc 158:416-431. https://doi.org/10.1007/s12010-008-8369-y

Galai S, Lucas-Elio P, Marzouki MN, Sanchez-Amat A (2011) Molecular cloning of a copper-dependent laccase from the dye-decolorizing strain Stenotrophomonas Maltophilia AAP56. J Appl Microbiol 111:1394-1405. https:// doi.org/10.1111/j.1365-2672.2011.05164.x

Galai S, Touhami Y, Marzouki MN (2012) Response surface methodology applied to laccase activities exhibited by Stenotrophomonas maltophilia AAP56 in different conditions. Bioresour Technol 7:706-726

Gao S, Seo JS, Wang J, Keum YS, Li J, Li QX (2013) Multiple degradation pathways of phenanthrene by Stenotrophomonas maltophilia C6. Int Biodeterior Biodegrad 79:98-104. https://doi.org/10.1016/j.ibiod.2013.01.012

Gomare S, Tamboli D, Kagalkar A, Gowindwar S (2009) Eco friendly biodegradation of a reactive textile dye Golden Yellow H ER by Brevibacillus laterosporus MTCC 2298. Int Biodeterior Biodegrad. https://doi.org/10. 1016/j.ibiod.2009.03.005

Han S, Han W, Chen J et al (2020) Bioremediation of malachite green by cyanobacterium Synechococcus elongatus PCC 7942 engineered with a triphenylmethane reductase gene. Appl Microbiol Biotechnol 104:3193-3204. https://doi.org/10.1007/s00253-020-10438-w

Hassaan MA, Nemr AE (2016) Health and environmental impacts of dyes: minireview. Am J Environ Sci Eng 1:64-67. https://doi.org/10.11648/j.ajese. 20170103.11

Huan-Mei L-T, Cai-Fang, et al (2011) Biodegradation of malachite green by strain Pseudomonas sp. K9 and cloning of the tmr2 gene associated with 
an ISPpu12. World J Microbiol Biotechnol 27:1323-1329. https://doi.org/ 10.1007/s11274-010-0580-7

Jadhav JP, Govindwar SP (2006) Biotransformation of malachite green by Saccharomyces cerevisiae MTCC 463. Yeast 23:315-323. https://doi.org/10. 1002/yea.1356

Jang MS, Lee YM, Kim CH, Lee JH, Lee YC (2005) Triphenylmethane reductase from Citrobacter sp. Strain KCTC18061 P: purification, characterization, gene cloning, and overexpression of a functional protein in Escherichia coli. Appl Environ Microbiol 71:7955-7960. https://doi.org/10.1128/AEM. 71.12.7955-7960.2005

Khan R, Bhawana P, Fulekar MH (2012) Microbial decolorization and degradation of synthetic dyes: a review. Rev Environ Sci Bio 12:75-97. https://doi. org/10.1007/s11157-012-9287-6

Kim MH, Kim Y, Park HJ, Lee JS, Kwak SN, Jung WH, Lee SG, Kim D, Lee YC, Oh TK (2008) Structural insight into bioremediation of triphenylmethane dyes by Citrobacter sp. triphenylmethane reductase. J Biol Chem 283:3198131990. https://doi.org/10.1074/jbc.M804092200

Kuppusamy S, Sethurajan M, Kadarkarai M, Aruliah R (2017) Biodecolourization of textile dyes by novel, indigenous Pseudomonas stutzeri L1 and Acinetobacter baumanniilL2. J Environ Chem Eng. 5:716-724. https://doi.org/10. 1016/j.jece.2016.12.021.0

Lee Y, Hendson M, Panopoulos NJ, Schroth MN (1994) Molecular cloning, chromosomal mapping, and sequence analysis of copper resistance genes from Xanthomonas campestris pv. juglandis: homology with small copper proteins and multicopper oxidases. J Bacteriol 176:173-188

Li LT, Hong Q, Yan X, Fang GH, Ali SW, Li SP (2009) Isolation of a malachite green-degrading Pseudomonas sp. MDB-1 strain and cloning of the tmr 2 gene. Biodegradation 20:769-776. https://doi.org/10.1007/ s10532-009-9265-z

Liu Z, Yang C, Qiao C (2007) Biodegradation of p-Ni-trophenol and 4 chlorophenol by Stenotrophomonas sp. FEMS Microbiol Ecol 277:150-156. https://doi.org/10.1111/j.1574-6968.2007.00940.x

Mutafov S, Avramova T, Stefanova L, Angelova B (2006) Decolorization of acid orange 7 by bacteria of different tinctorial type: a comparative study. World J Microb Biot 23:417-422. https://doi.org/10.1007/ s11274-006-9241-2

Muthukumarasamy NP, Jackson B, Raj AJ, Sevanan M (2015) Production of extracellular laccase from Bacillus subtilis MTCC 2414 using agroresidues as a potential substrate. Biochem Res Int. https://doi.org/10.1155/2015/ 765190

Narayanan MP, Murugan S, Eva AS, Devina SU, Kalidass S (2015) Application of immobilized laccase from Bacillus subtilis MTCC 2414 on decolourization of synthetic dyes. Res J Microbiol 10:421-432. https://doi.org/10.3923/jm. 2015.421 .432

Narayanan PM, Murugan S (2014) Production, purification and application of bacterial laccase: a review. Biotechnology 13:196-205

Pandey A, Singh P, lyengar L (2007) Bacterial decolorization and degradation of azo dyes. Int Biodeterior 59:73-84. https://doi.org/10.1016/j.ibiod.2006. 08.006

Parshetti G, Kalme S, Saratale G, Govindwar S (2006) Biodegradation of malachite green by Kocuria rosea MTCC 1532. Acta Chim Slov 53:492-498

Pradhan P, Kumar HD, Gireesh Babu K (2012) Degradation of azo and triphenylmethane dye by the bacteria isolated from local industrial waste. IJCRR 4:39-49

Prins A, Kleinsmidt L, Khan N, Kirby B, Kudanga T, Vollmer J et al (2015) The effect of mutations near the T1 copper site on the biochemical characteristics of the small laccase from Streptomyces coelicolor A3(2). Enzyme Microb Technol 68:23-32. https://doi.org/10.1016/j.enzmictec.2014.10. 003

Raghukumar C, D'Souza-Ticlo D, Verma AK (2008) Treatment of colored effluents with lignin-degrading enzymes: an emerging role of marine-derived fungi. Crit Rev Microbiol 34:189-206. https://doi.org/10.1080/1040841080 2526044

Rajesh KS, Uttam CB (1999) Decolorization of triphenylmethane dyes and textile and dyes-stuff effluent by Kurthia sp. Enzyme Microb Technol 24:433-437. https://doi.org/10.1016/S0141-0229(98)00159-8

Rajeswari K, Kumar SR, Vijayaraman K (2015) Decolorization and degradation of textile dyes by Stenotrophomonas maltophilia RSV-2. Indian Streams Res J 5:1-13. https://doi.org/10.12691/ijebb-1-2-5

Reiss R, Ihssen J, Richter M, Eichhorn E, Schilling B et al (2013) Laccase versus laccase-like multi-copper oxidase: a comparative study of similar enzymes with diverse substrate spectra. PLoS ONE 8:e65633. https://doi. org/10.1371/journal.pone.0065633

Robinson T, McMullan G, Marchant R, Nigam P (2001) Remediation of dyes in textile effluent: a critical review on current treatment technologies with a proposed alternative. Bioresour Technol 77:247-255. https://doi.org/10. 1016/s0960-8524(00)00080-8

Ryan RP, Monchy S, Cardinale M, Taghavi S, Crossman L et al (2009) The versatility and adaptation of bacteria from the genus Stenotrophomonas. Nat Rev 7:514-525

Sakamoto Y, Nakade K, Yoshida K, Natsume S, Miyazaki K, Sato S, van Peer AF, Konno N (2015) Grouping of multicopper oxidases in Lentinula edodes by sequence similarities and expression patterns. AMB Express 5:63. https://doi.org/10.1186/s13568-015-0151-2

Sambrook J, Fritschi EF, Maniatis T (1989) Molecular cloning: a laboratory manual. Cold Spring Harbor Laboratory Press, New York

Saratale RG, Saratale GD, Chang JS, Govindwar SP (2011) Bacterial decolourization and degradation of azo dyes: a review. J Taiwan Inst Chem Eng 42:138-157. https://doi.org/10.1016/j.jtice.2010.06.006

Selvakumar S, Manivasagan R, Chinnappan K (2013) Biodegradation and decolourization of textile dye wastewater using Ganoderma lucidum. 3 Biotech 3:71-79. https://doi.org/10.1007/s13205-012-0073-5

Shah MP, Patel KA, Nair SS, Darji AM (2013) Environmental bioremediation of dyes by Pseudomonas aeruginosa ETL-1 isolated from final effluent treatment plant of ankleshwar. Am J Microbiol Res 1:74-83. https://doi.org/10. 12691/ajmr-1-4-3

Shin KS, Kim CJ (1998) Decolorization of artificial dyes by peroxidase from the white-rot fungus, Pleurotus ostreatus. Biotechnol Lett 20:569-572. https:// doi.org/10.1023/A:1005301812253

Shraddha R, Shekher S, Sehgal M, Kamthania KA (2011) Laccase: microbial sources, production, purification, and potential biotechnological applications. Enzyme Res 2011:217861. https://doi.org/10.4061/2011/217861

Sneha U, Poornima R, Sridhar S (2014) Optimization and decolorization of malachite green using Pseudomonas putida. J chem pharm res 6:50-57

Tamura K, Nei M (1993) Estimation of the number of nucleotide substitutions in the control region of mitochondrial DNA in humans and chimpanzees. Mol Biol Evol 10:512-526. https://doi.org/10.1093/oxfordjournals.molbev. a040023

Tekere M, Mswaka AY, Zvauya R, Read JS (2001) Growth, dye degradation and ligninolytic activity studies on Zimbabwean white-rot fungi. Enzyme Microb Technol 28:420-426. https://doi.org/10.1016/S0141-0229(00) 00343-4

Unuofin JO (2020) Sustainability potentials of novel laccase tinctures from Stenotrophomonas maltophilia BIJ16 and Bordetella bronchiseptica HSO16: From dye decolourization to denim bioscouring. Biotechnology Reports 25:e00409. https://doi.org/10.1016/j.btre.2019.e00409

Unuofin JO, Moubasher HA, Okoh Al, Nwodo UU (2019) Production of Polyextremotolerant laccase by Achromobacter xylosoxidans HWN16 and Citrobacter freundii LLJ16. Biotechnology Reports 24:e00337. https://doi. org/10.1016/j.btre.2019.e00337

Urszula G, Izabela G, Danuta W, Sylwia L (2009) Isolation and characterization of a novel strain of Stenotrophomonas maltophilia possessing various dioxy-genases for monocyclic hydrocarbon degradation. Braz J Microbiol 40:285-291. https://doi.org/10.1590/S1517-838220090002000014

Van der Zee FP, Lettinga G, Field JA (2001) Azo dye decolorization by anaerobic granular sludge. Chemosphere 44:1169-1176. https://doi.org/10.1016/ S0045-6535(00)00270-8

Vijayalakshmidevi SR, Muthukumar K (2014) Biodegradation of malachite green by Ochrobactrum sp. World J Microbiol Biotechnol 30:429-437. https://doi.org/10.1007/s11274-013-1452-8

Wang J, Gao F, Liu Z, Qiao M, Niu X, Zhang K, Huang X (2012) Pathway and molecular mechanisms for malachite green biodegradation in Exiguobacterium sp. MG2. PLoS ONE 7:e51808. https://doi.org/10.1371/journal. pone.0051808

Wang J, Qiao M, Wei K, Ding J, Liu Z, Zhang KQ, Huang X (2011) Decolorizing activity of malachite green and its mechanisms involved in dye biodegradation by Achromobacter xylosoxidans MG1. J Mol Microb Biotech 20:220-227. https://doi.org/10.1159/000330669

Wanyonyi WC, Onyan JM, Shiundu PW, Mulaa FJ (2017) Biodegradation and detoxification of melachite green dye using novelenzymes from Bacillus cereus strain KM201428: Kinetic and Metabolite Analysis. Energy Procedia 119:38-51. https://doi.org/10.1016/j.egypro.2017.07.044 
Wu J, Jung B, Kim K, Lee Y, Sung N (2008) Isolation and characterization of Pseudomonas otitidis WL-13 and its capacity to decolorize triphenylmethane dyes. Int J Environ Sci 21:960-964. https://doi.org/10.1016/s10010742(08)62368-2

Yang J, Yang X, Lin Y, Ng T, Lin J, Ye X (2014) Laccase-catalyzed decolorization of malachite green: performance optimization and degradation mechanism. PLoS ONE 10:e0127714. https://doi.org/10.1371/journal.pone.01277 14

Zhang L, Li XZ, Poole K (2001) Fluoroquinolone susceptibilities of efflux mediated multidrug-resistant Pseudomonas aeruginosa, Stenotrophomonas maltophilia, and Burkholderia cepacia. Description J Antimicrob Chemother 48:549-552. https://doi.org/10.1093/jac/48.4.549
Zouch H, Cabrol L, Chifflet S, Tedetti M, Karray F, Zaghden H, Sayadi S, Quéméneur M (2018) Effect of acidic industrial effluent release on microbial diversity and trace metal dynamics during resuspension of coastal sediment. Front Microbiol 9:3103. https://doi.org/10.3389/fmicb.2018.03103

\section{Publisher's Note}

Springer Nature remains neutral with regard to jurisdictional claims in published maps and institutional affiliations.

\section{Submit your manuscript to a SpringerOpen ${ }^{\circ}$ journal and benefit from:}

- Convenient online submission

- Rigorous peer review

- Open access: articles freely available online

- High visibility within the field

- Retaining the copyright to your article

Submit your next manuscript at $\boldsymbol{\nabla}$ springeropen.com 